\title{
2008 Küresel Krizi Öncesi ve Sonrası Dönemde Seçilmiş Avrasya Ekonomilerinin Türkiye ile Olan Dış Ticareti'nin Panel Veri Yöntemi ile Analizi
}

\author{
An Analysis of the Foreign Trade between Selected Eurasian Economies and Turkey \\ Before and After the Period of 2008 Financial Crisis with Panel Data Method
}

\author{
Dr. Öğr. Üyesi Ali Konak - Dr. Öğr. Üyesi Hayrettin Kesgingöz
}

\begin{abstract}
Başvuru Tarihi: 17.04.2018
\end{abstract}
Kabul Tarihi: 24.12.2018

\section{Öz}

Günümüzde, ekonomik açıdan gittikçe önem kazanan Avrasya ülkeleri diğer ülkeler açısından önemli bir ticari partner haline gelmiş durumdadir. Gelişen dünyada küresel ekonomik yapının önemli bir parçasını teşkil eden Avrasya ülkeleriyle Türkiye arasında ticari açıdan ciddi bir etkileşimin söz konusu olduğuna ve bu ülkelerle Türkiye arasinda, mal ve hizmet ticareti açısından büyük bir potansiyelin bulunduğuna değinmekte yarar vardir.

Küresel nitelikteki 2008 krizinde ve krizden sonraki yıllarda Avrasya ülkeleriyle Türkiye arasindaki dış ticaretin yapısın ve gelişimini analiz etmek amacıla hazırlamış olduğumuz çalışmamızda, ekonometrik model olarak panel veri analiz yöntemi kullanılmıştır. Elde edilen amprik bulgular neticesinde, Azerbaycan, Belarus, Gürcistan, Kirgizistan, Kazakistan, Moldova, Rusya, Türkiye ve Ukrayna'nın sabit sermaye yatırımlarının, döviz kurunun ve büyümenin dış ticaret üzerine olumlu etkisi olduğu sonucuna ulaşılmıştır.

Anahtar Kelimeler: Küresel Kriz, Avrasya Ekonomileri, Dış Ticaret, Küreselleșme, Türk Ekonomisi

\begin{abstract}
Nowadays, Eurasiancountries, whicharebecomingmoreandmoreimportant in economicterms, havebecome an importanttrade partner forothercountries. There is a significantcommercialinteractionbetweenTurkeyandtheEurasiancountrieswhichconstitute an importantpart of the global economicstructure in thedeveloping World andit would be beneficialtostatethatthere is greatpotentialbetweenthesecountriesandTurkeyforthetrade of goodsandservices.
\end{abstract}

In the global 2008 crisisandtheyearsafterthecrisis, wehavepreparedforthepurpose of analyzingthestructureanddevelopment of foreigntradebetweentheEurasiancountriesandTurkey, the Panel data analysismethodwasused as an econometric model. As a result of theempiricalfindings, Azerbaijan, Belarus, Georgia, Kyrgyzstan, Kazakhstan, Moldova, Russia, TurkeyandUkraine'sfixedcapitalinvestments, exchange rate andconcluded that thepositiveeffect on thegrowth of foreigntrade has beenreached.

Keywords: Global Crisis, EuroasianEconomies, ForeignTrade, Globalization, TurkishEconomy

Dr. Öğr. Üyesi. Ali Konak, Karabük Üniversitesi İİBF İktisat Bölümü, alikonak@karabuk.edu.tr, ORCID: 0000-0003-1804-8339 Dr. Öğr. Üyesi Hayrettin Kesgingöz, Karabük Üniversitesi İ̉BF İktisat Bölümü, hayrettinkesgingoz@karabuk.edu.tr, ORCID: 0000-0002-5143-4891 


\section{Giriş}

Ülkenin ekonomik gelişimi açısından diş ticaret faaliyetleri büyük bir öneme sahiptir. Ülkelerin hiçbiri gerek üretim faktörlerinin gerekse tüketim mallarının tamamına sahip olmadıkları için diğer ülkelerle ticaret yapmak zorundadır. Ülke üretiminin ve ihracat1nın artırılması neticesinde ülkeye yönelik olarak gerçekleşen sermaye akışı, hem yatırımların güçlenmesine ve diş ticaret haddinin iyileşmesine hem de üretim kalitesi açısından rekabet gücünün kazanılmasına olumlu katkılar sağlamaktadır. Günümüzde Türkiye, dış ticaret potansiyeli açısından oldukça önemli bir ülke haline gelmiştir ve Avrasya ülkeleri ile yapılan ticaret önemli bir hacme ulaşmıştır. 2008 yılındaki küresel krizi ve sonrasında Avrasya ekonomilerinin Türkiye ile gerçekleştirdikleri dış ticaret faaliyetlerini analiz etmek amacıyla panel veri analiz yöntemi kullanılarak hazırlanan bu çalışmada, dış ticari faaliyetler açısından mevcut durum ortaya konularak önem arz eden eksiklikler tespit edilmiş ve çözüm önerilerinde bulunulmuştur.

\section{Dış Ticaret ve Özellikleri}

Küreselleşme sürecinde meydana gelen değişimlerin, dış ticaret faaliyetlerinin gelişimi üzerinde önemli etkileri vardır. Dış ticaret faaliyetleri sayesinde, birbirinden farklı yerlerdeki üretici ve tüketiciler, çeşitli ticari kanallar aracilığıyla bir araya gelmekte ve ticarete konu olan mallar ülkeler arasında el değiştirmektedir. Ayrıca dış ticaret faaliyetleri, satıcılar açısından en iyi müşterinin aranmasına ve alıcılar açısından da en uygun fiyatla aynı zamanda da kaliteli mal satı̧sı yapan satıcıların bulunmasına olanak sağlamaktadır (Taylor, 2002, s.40-44). Bu süreçte uluslararası piyasalardaki iktisadi ve ticari bütünleşme girişimlerine bağlı olarak hızlanan küreselleşme eğilimleri, dış ticaret faaliyetlerinin öneminin son yıllarda daha da artmasına neden olmuştur. Ayrıca küreselleşmenin hızlanmasıyla birlikte diş ticaret faaliyetlerinden elde edilen getiriler, ülkeye giren döviz miktarındaki artışa bağlı olarak ülkedeki yatırımlarda artışlara ve dolayısıyla ülke refahının artmasına katkıda sağlamaktadır (Sharma ve Dietrich, 2004, s.3).

Diş ticaret faaliyetleri ve bunlardan edilebilecek gelirler, bütün ülkeler için önemli olmakla birlikte ekonomik ve siyasi bağımsızlı̆̆ını yeni ilan eden ülkeler (ekonomik açıdan "küçük" olarak ifade edilebilecek ülkeler) için çok daha büyük bir önem arz etmektedir. Özellikle Sovyet Sosyalist Cumhuriyetler Birliğinin (SSCB’nin) 1991 yılında dağılmasının ardından, bağımsızlıklarını kazanan Avrasya ülkelerinin önceki üretim yapıları ve ticari faaliyetleri incelenmesi gereken bir alanı oluşturmaktadır. Bu konuda daha önce yapılan çalışmalara yönelik bir literatür taraması yapıldığında farklı sonuç ve görüşlerin ortaya çıktığı görülmektedir.

\section{Literatür Taraması}

Narin ve Maşrap (2010), 2008 yllında yaşanan küresel nitelikteki ekonomik kriz sonrası Türk cumhuriyetlerinin ekonomilerinde meydana gelen gelişmeleri ve bu ülkelerin Türkiye ile yaptıkları ticari faaliyetler üzerindeki etkilerini incelemek amacıyla bir çalışma gerçekleştirmişlerdir. Yapılan çalışmada, 2009 y1lında Türk Cumhuriyetleri’nin büyüme oranlarında kısmi düşüşlerin yaşanmasına karşın 2008 yılında yaşanan küresel ekonomik krizinden Türkmenistan, Azerbaycan ve Kazakistan dışındaki ülkelerin çok da fazla etkilenmediği tespit edilmiştir. Türkmenistan, Azerbaycan ve Kazakistan'in 2008 yılında yaşanan küresel ekonomik krizinden çok fazla etkilenmesinde ise dünya piyasasında bu ülkelerin sahip olduğu enerji kaynaklarının (petrol ve doğal gaz) fiyatlarındaki azalışların etkili olduğu sonucuna ulaşılmıştır. Ayrıca aynı çalışmada, Türk Cumhuriyetleri’nin Türkiye ile olan diş ticaretlerinin zaman içerisinde artmasına karşın hâlâ düşük seviyelerde olduğu ve 2008 yllında yaşanan küresel ekonomik krizin, Türk Cumhuriyetlerỉnin Türkiye ile olan ticaretini çok fazla etkilemediği tespit edilmiştir.

Karluk (2011) 2008 yllında yaşanan küresel krizin Kırgızistan ekonomisine etkisini ve Türkiye-Kırgızistan ekonomik ilişkilerindeki gelişmeleri, 2000-2010 dönemine için TÜİK ve Kırgızistan Milli İstatistik Kurumundan elde ettiği çeşitli verilerden yararlanarak incelemiştir. Yapılan inceleme sonucunda 2008 yilında yaşanan küresel finansal krizin ve 2010 yılında yaşanan halk ayaklanmasının Türkiye ile Kırgızistan arasındaki dış ticareti olumsuz yönde etkilediği, buna bağlı olarak da 2010 yılında iki ülke arasındaki dış ticaret hacminde bir miktar daralmanın olduğu tespit edilmiştir. 
Solak ve Sarıdoğan (2011), ise 2008 yılında yaşanan küresel nitelikli ekonomik krizin Özbekistan, Türkmenistan, Kazakistan, Azerbaycan ve Kirgızistan üzerindeki makroekonomik etkilerini karşılaştırmalı olarak inceledikleri çalışmada, söz konusu ülkelerin krizden farklı düzeylerde etkilendikleri ve bu farklılığın incelenen ülkelerin ekonomik yapılarından, diğer ülkelere olan bağımlılık seviyelerinden ve dış dünyaya entegrasyonlarından kaynaklandığı sonucuna ulaşmışlardır. Ayrıca ülkelerin ortaya çıkması muhtemel iç ve dış şoklar karşısındaki hassasiyetlerini azaltmak için küresel rekabet gücünü artırmaya yönelik iktisat politikalarını geliştirmeleri gerektiği tespitinde bulunmuşlardır.

Golovko (2013), çalışmasında pek çok açıdan birbirine benzemekle birlikte bazı açılardan kendilerine has farklılıklara sahip olan Avrasya ülkelerinin merkezi planlamadan piyasa ekonomisine geçmeleri sonrasında, ihracatlarında konsantrasyon derecesinin / çeşitliliğinin artırıp artırmadığını, ihraç ürünlerinin sayısı ve Herfindahl - Hirschman (HH) ürün konsantrasyon endeksi yardımıyla analiz etmiştir. Yapılan analiz neticesinde Rusya dışındaki Avrasya ülkelerinin tamamında ihraç ürünleri sayısının arttığı ve bundan dolayı ihraç edilen ürünlerin çeşitlerinde gelişme yaşandığ 1 , ayrıca ihraç edilen ürünlerin ticari değerinin dağılımını ölçen HH endeksinin aynı dönemde genel olarak arttığı sonucuna ulaşılmıştır. Bu sonuç Avrasya ülkelerinin ihracatında ürün konsantrasyonunun arttığını ve söz konusu ülkelerin ekonomilerinin dış ticaret kaynaklı şoklara ve küresel nitelikteki krizlere karşı daha duyarlı hale geldiğini göstermektedir.

Mercan (2014)'da çalışmasında Kırgızistan, Azerbaycan, Türkmenistan, Özbekistan, Kazakistan, Tacikistan ve Türkiye açısından ekonomik büyümeyi belirleyen faktörleri ve 2008 küresel krizinin bu ülkelerin ekonomik büyümeleri üzerindeki etkilerini 1990-2012 dönemi verileri kullanılarak incelemiștir. Çalışmada panel veri analizi yöntemi kullanılmıştır. Yapılan analiz neticesinde, incelenen ülke ekonomilerinin büyümesinde en çok katkının sırasıyla; kamu harcamalarından, ihracattan ve özel tüketim harcamalarından kaynaklandığı, ihracatın büyüme üzerindeki etkisinin beklendiği üzere yüksek ve istatistikî olarak anlamlı çıktığ 1 ve 2008 ekonomik krizinin incelenen ülkelerin ekonomik büyümesi üzerindeki etkisinin negatif ve istatistikî olarak anlamlı olduğu tespit edilmiştir.
Kesgingöz (2015), döviz kurundaki değişimin Türkiye-Kırgızistan dış ticaretine etkisini, 1993-2014 dönemi için dünya bankası veri tabanından temin ettiği aylık döviz kuru, ihracat ve ithalat verilerini kullanarak, Vektör Otoregresif (VAR) yöntemiyle analizi ettiği çalışmasında, döviz kurundaki değişmelerin incelenen iki ülkenin dış ticareti üzerinde herhangi bir etkisinin olmadığı sonucuna ulaşmıştır.

Hazırlamış olduğumuz bu çalışmada iktisadi açıdan gelişmekte olan Avrasya ülkelerinin ekonomik yap1ları, bu ülkelerin dış ticaretindeki gelişmeleri ve dönem dönem yaşanan krizlerin etkisiyle Avrasya ülkelerinin dış ticaretinde meydana gelen değişmeleri inceleyerek sonuçları değerlendirmek konunun anlaşılması açısından önemli katkılarda sağlayacaktır.

\section{Avrasya Ülkelerinin Dış Ticaret Yapısı ve Gelişimi}

Avrasya ülkelerinin, kriz yılları hariç olmak üzere yıldan yıla uyguladıkları dış ticaret politikasıyla ihracat hacimlerini dolayısıyla da dış ticaret hacimlerini düzenli olarak artırdıkları görülmektedir. Avrasya ülkeleri olarak bilinen ülkeler, Belarus, Gürcistan, Kazakistan, Kırgizistan, Moldova, Özbekistan, Rusya, Tacikistan, Türkmenistan, Ukrayna ve Azerbaycan'dır. Buna karşın Türkmenistan,Özbekistan ve Tacikistan ülkelerine ait veri setleri Dünya Bankası veri tabanında yıllar itibariyle eksik olduğundan dolayı adı geçen ülkeler inceleme dışı bırakılmıştır. Ayrıca inceleme yapılan bazı ülkeler için de 2017 yılına ait verilerde eksiklikler söz konusudur. 2017 yılına ait verilerdeki eksiklilerin neden olacağı sorunları ortadan kaldırmak ve düzenli bir veri seti elde etmek amaciyla çalışmada 2016 yılına ait veriler kullanılmıştır.

İktisadi gelişmişlik ve dış ticaret hacmi açısından Avrasya ekonomileri içerisinde yer alan en önemli 5 ülkenin diş ticaretindeki gelişmeleri incelemekte yarar vardır.Bu bağlamda Avrasya ülkeleri içerisinde yer alan Rusyảnın, bu ülke grubu içerisindeki en önemli dış ticaret potansiyeline sahip ülke konumunda olduğu görülmektedir. Trademap (2016:1a) verilerine göre 2003 yılından sonraki dönemde Rusya’nın en çok ihracat yaptığı ülkelerin sıralaması yıllar itibariyle değişiklik göstermiş olmakla birlikte 2016 yılında en çok ihracat yapılan ülkeler Hollanda, Çin, Almanya, Belarus, Türkiye ve İtalya olmuştur. Yine 2016 yilı itibariyle Rusya'nın ithalatında en önemli paya sahip 
olan ülkeler ise Çin, Almanya ve Amerika Birleşik Devletleridir. Hollanda, 2004 yilından 2016 yılına kadar geçen süreçte (2016 yılı dahil) aralıksız olarak Rusyảnın ihracat yaptığı en önemli ticari partner konumundaki ülkedir. İthalatta ise 2008 yllından 2016 yllına kadar geçen süreçte yine aralıksız olarak Çin, Rusya’nın en büyük ticari partneri konumundadır.

İncelenen dönem içerisinde 22 Ağustos 2012 tarihi hem dünya ticareti hem de Rusya dış ticareti açısından önemli bir tarihtir. Bu tarih itibariyle uzun süre devam eden görüşmelerin sonunda Rusya Dünya Ticaret Örgütüne üye olarak dünya ticaretine entegre olma yönünde önemli bir ilerleme kaydetmiştir (İstanbul Tekstil ve Konfeksiyon İhracatçı Birlikleri, 2013, s.6). Bu sayede Rusyảnın diş ticaretinin daha hızlı ve pozitif yönde gelişmesi hedeflenmiş ve bu doğrultuda gelişmeler yaşanmıştır. Ayrıca Rusya, Avrasya bölgesinde faydacı bir yaklaşımla Avrupadan Çin’e kadar uzanan geniş bir coğrafyada tüm ticaret ve enerji akımlarının merkezi haline gelebilmek için Avrasyacılık görüşünü kullanmakta ve bölgenin tek hakim gücü olmayı arzu etmektedir (Rangsimaporn, 2006, s.371-389).

Tablo 1 ve Tablo 2 incelendiğinde Rusyảnın hem ihracatının hem de ithalatının incelenen dönem içerisinde 2009 yılına kadar sürekli artış gösterdiği görülmektedir. 2008 yılında yaşanan küresel kriz, ülkenin hem ihracat hem de ithalat seviyesinde büyük miktarlarda azalışların yaşanmasına neden olmuştur. Sonraki yıllarda yine ihracat ve ithalat miktarlarında artışlar ve azalışlar yaşandığı ama azalışların hiçbirinin 2009 yılındaki azalış kadar büyük hacimli olmadığ ihracatı 285,4 milyar dolar ve ithalatı da 182,2 milyar dolar olarak gerçekleşmiş bulunmaktadır.
Rusyadan sonra Avrasya ülkeleri içinde yer alan bir diğer önemli ve büyük ekonomi ise Ukrayna ekonomisidir. Ukrayna, ihracattaki kota ve lisans uygulamalarını hafifleterek uluslararası ekonomik sisteme entegre olmaya başlamış, dış ticarette geçerli olan muhasebe sistemleri basitleştirilmiş ve bu sayede ulusal ekonomisini dünyaya açmıştır. Ukrayna’nın ihracat gelirleri, demir-çelik ve tarım sektörlerindeki gelişmelere bağlı olarak değişim göstermektedir. Ukrayna’nın ana ihraç kalemini teşkil eden demir-çelik ürünlerine yönelik talepte meydana gelen değişmeler Ukrayna’nın ihraç gelirlerini doğrudan etkilemektedir. Buna karşın ülkenin ithalat harcamalarında eski Sovyet ülkeleri ve özellikle de Rusya'dan yapılan doğalgaz ve petrol şeklindeki enerji ithalatı önemli bir paya sahiptir (Türkiye Ukrayna Sanayici ve İşadamları Birliği, 2013, s.5-8). Tablo 1 ve Tablo 2 incelendiğinde, 2009 yllı öncesi artış eğiliminde olan ihracat ve ithalat rakamlarının, 2009 yilında, 2008 yılında yaşanan küresel krizin etkisiyle önemli miktarda gerilediği görülmektedir. 2008 yılından sonraki dönem de ise hem ihracat hem de ithalat rakamlar1nın sınırlı seviyelerde de olsa arttığı ancak son yıllarda azalış eğiliminin ağırlık kazandığı görülmektedir. 2016 yll itibariyle Ukrayna'nın toplam ihracatı 36,8 milyar dolar, toplam ithalatı ise 38,2 milyar dolar olarak gerçekleşmiştir. Ukraynảnın en çok ihracat yaptığı ülkeler, Rusya, Türkiye, Çin, Mısır ve İtalya'dır. İncelenen dönem (2003-2016) itibariyle Rusya, aralıksız olarak her yıl Ukrayna'nın ihracatında ve ithalatında en önemli ticari partner ülke olmuştur. 2016 yılı itibariyle Ukrayna’nın en çok ithalat yaptığı ülkeler ise sırasıyla Rusya, Almanya ve Çin'dir. 
Tablo 1. Avrasya Ülkelerinin Toplam Ürün Ihracatı

\begin{tabular}{|c|c|c|c|c|c|c|c|}
\hline & \multicolumn{7}{|c|}{ Milyar ABD Dolar } \\
\hline & 2003 & 2004 & 2005 & 2006 & 2007 & 2008 & 2009 \\
\hline Ukrayna & 23.0 & 32.6 & 34.2 & 38.3 & 49.2 & 66.9 & 39.6 \\
\hline Belarus & 9.9 & 13.7 & 15.9 & 19.7 & 24.2 & 32.5 & 21.3 \\
\hline Moldova & 0.7 & 0.9 & 1.0 & 1.0 & 1.3 & 1.5 & 1.2 \\
\hline Rusya & 133.6 & 181.6 & 241.4 & 301.5 & 352.2 & 467.9 & 301.7 \\
\hline Gürcistan & 0.4 & 0.6 & 0.8 & 0.9 & 1.2 & 1.4 & 1.1 \\
\hline Azerbaycan & 2.5 & 3.6 & 4.3 & 6.3 & 6.0 & 47.7 & 14.6 \\
\hline Kazakistan & 12.9 & 20.0 & 27.8 & 38.2 & 47.7 & 71.1 & 43.1 \\
\hline Kırgızistan & 0.5 & 0.7 & 0.6 & 0.7 & 1.1 & 1.6 & 1.1 \\
\hline \multirow[t]{3}{*}{ Türkiye } & 47.2 & 63.1 & 73.4 & 85.5 & 107.2 & 132.0 & 102.1 \\
\hline & \multicolumn{7}{|c|}{ Milyar ABD Dolar } \\
\hline & 2010 & 2011 & 2012 & 2013 & 2014 & 2015 & 2016 \\
\hline Ukrayna & 51.4 & 68.3 & 68.6 & 63.3 & 53.9 & 38.1 & 36,8 \\
\hline Belarus & 25.2 & 41.4 & 46.0 & 37.2 & 36.0 & 26.6 & 23.4 \\
\hline Moldova & 1.5 & 2.2 & 2.1 & 2.4 & 2.3 & 1.9 & 2.0 \\
\hline Rusya & 397.0 & 516.9 & 524.7 & 527.2 & 497.8 & 343.9 & 285.4 \\
\hline Gürcistan & 1.5 & 2.1 & 2.3 & 2.9 & 2.8 & 2.2 & 2.1 \\
\hline Azerbaycan & 21.2 & 26.4 & 23.8 & 23.9 & 21.7 & 22.8 & 23.4 \\
\hline Kazakistan & 57.2 & 88.1 & 92.2 & 84.6 & 79.4 & 45.9 & 36.7 \\
\hline Kurglzistan & 1.4 & 1.9 & 1.6 & 1.7 & 1.8 & 1.4 & 1.4 \\
\hline Türkiye & 113.9 & 134.9 & 152.4 & 151.8 & 157.6 & 143.8 & 142.6 \\
\hline
\end{tabular}

Kaynak: Trademap, http://www.trademap.org/ (2016:1b.),

(Erişim Tarihi : 24.10.2017) ve (2016:1c.), (Erişim Tarihi : 24.10.2017)

IMF, http://data.imf.org/regular.aspx?key=60998117

(Erişim Tarihi : 28.10.2017)

(Tablo, yukarıda belirtilen sitelerde yer alan verilerden yararlanılarak tarafımızca hazırlanmıştır.) 
Tablo 2. Avrasya Ülkelerinin Toplam Ithalatı

\begin{tabular}{|c|c|c|c|c|c|c|c|}
\hline & \multicolumn{7}{|c|}{ Milyar ABD Dolar } \\
\hline & 2003 & 2004 & 2005 & 2006 & 2007 & 2008 & 2009 \\
\hline Ukrayna & 23.0 & 28.9 & 36.1 & 45.0 & 60.6 & 85.4 & 45.4 \\
\hline Belarus & 11.5 & 16.3 & 16.6 & 22.3 & 28.6 & 39.3 & 28.5 \\
\hline Moldova & 1.4 & 1.7 & 2.2 & 2.6 & 3.6 & 4.8 & 3.2 \\
\hline Rusya & 57.3 & 75.5 & 98.7 & 137.8 & 199.7 & 267.0 & 170.8 \\
\hline Gürcistan & 1.1 & 1.8 & 2.4 & 3.6 & 5.2 & 6.0 & 4.3 \\
\hline Azerbaycan & 2.6 & 3.5 & 4.2 & 5.2 & 5.7 & 7.1 & 6.1 \\
\hline Kazakistan & 8.4 & 12.7 & 17.3 & 23.6 & 32.6 & 37.8 & 28.4 \\
\hline Kurglzistan & 0.7 & 0.9 & 1.1 & 1.7 & 2.4 & 4.0 & 2.9 \\
\hline \multirow[t]{3}{*}{ Türkiye } & 69.3 & 97.5 & 116.7 & 139.5 & 170.0 & 201.9 & 140.8 \\
\hline & \multicolumn{7}{|c|}{ Milyar ABD Dolar } \\
\hline & 2010 & 2011 & 2012 & 2013 & 2014 & 2015 & 2016 \\
\hline Ukrayna & 60.7 & 82.6 & 84.6 & 76.9 & 54.3 & 37.5 & 38.2 \\
\hline Belarus & 34.8 & 45.7 & 46.4 & 43.0 & 40.5 & 30.2 & 27.4 \\
\hline Moldova & 3.8 & 5.1 & 5.2 & 5.4 & 5.3 & 3.9 & 4.0 \\
\hline Rusya & 228.9 & 306.0 & 316.1 & 314.9 & 286.6 & 182.7 & 182.2 \\
\hline Gürcistan & 5.0 & 7.0 & 8.0 & 8.0 & 8.6 & 7.7 & 7.2 \\
\hline Azerbaycan & 6.5 & 9.7 & 9.6 & 10.7 & 9.1 & 9.2 & 7.1 \\
\hline Kazakistan & 24.0 & 38.0 & 44.5 & 48.8 & 41.2 & 30.1 & 25.1 \\
\hline Kırglzistan & 3.2 & 4.2 & 5.3 & 5.9 & 5.7 & 4.0 & 3.8 \\
\hline Türkiye & 185.5 & 240.8 & 236.5 & 251.6 & $24 . .1$ & 207.2 & 198.6 \\
\hline
\end{tabular}

Kaynak : Trademap, http://www.trademap.org/ (2016:1d.),

(Erişim Tarihi : 25.10.2017) ve (2016:1e.), (Erişim Tarihi : 25.10.2017) IMF, http://data.imf.org/

regular.aspx?key=60998117 (Erişim Tarihi : 28.10.2017)

(Tablo, yukarıda belirtilen sitelerde yer alan verilerden yararlanılarak tarafımızca hazırlanmıștır.)

Avrasya ekonomileri içerinde önemli ekonomik güce dış ticaret potansiyeline sahip bir diğer ülke de Belarus'dur. Ülkeye ait ihracat ve ithalat verilerinin yer aldığ 1 Tablo 1 ve Tablo 2 incelendiğinde Belarus'un ihracat ve ithalat değerlerinin diğer ülkeler gibi 2009 yılına kadar sürekli olarak arttığg ve Belarus'un da diğer ülkeler gibi 2008 yılında yaşanan krizden önemli oranda etkilendiği ve 2010 yılından itibaren de ülkenin ihracat ve ithalat değerlerinin önce artan 2013 y1lından itibaren de azalan bir eğilim sergilediği görülmektedir. Ülkenin toplam ihracatı 2016 yllı itibariyle 23,4 milyar dolar, ithalatı ise 27,4 milyar dolar olarak gerçekleșmiştir. Ülkede gerçekleştirilen üretiminin ithal girdilere bağımlı olması ve dış ticarette hammadde ile ara mallarının ithalatının büyük bir ağırlığa sahip olması, ülkenin ithalatının sürekli olarak artmasında önemli rol oynamaktadır (Dış Ekonomik İlişkiler Kurulu, 2012, s.12). Belerus'un en çok ihracat yaptığ 1 ve ihracat geliri elde ettiği en önemli ülkeler, Rusya, Ukrayna, İngiltere, Almanya ve Hollanda'dır. Ülkenin ithalatındaki en önemli ülkeler ise yine Rusya, Çin ve Almanya'dır. Rusya, Belarus'un hem ithalatında hem de ihracatında en önemli ülke konumundadir. 
Ekonomisi büyük ölçüde Rusya’ya bağlı bir Orta Asya ülkesi olan Kazakistan, bağımsızlığını kazandıktan sonra iç ve dış ticaretin liberalleșmesi adına bir takım önemli girișimlerde bulunmuștur. Bu bağlamda küçük sanayi işletmelerinin özelleşmesi için düzenlemeler yapılmış, fiyat, faiz ve enerji konularında doğrudan yabancı sermaye yatırımlarını ülkeye çekmeye yönelik liberalleşme gayretleri içinde olunmuş ve dışa açı bir kalkınma politikası izlenmiştir (Yayar vd., 2012, s.253). Rusya ve Ukrayna’nın diş ticaret rakamlarındakine benzer gelişmeler Kazakistan diş ticareti içinde geçerlidir.Trademap (2016:1f) verilerinden yararlanılarak hazırlanan Tablo 1 ve Tablo 2de 2009 yılı öncesi artış eğiliminde olan ihracat ve ithalat rakamlarının, 2009 yılında, 2008 yılında yaşanan küresel krizin etkisiyle önemli miktarda gerilediği görülmektedir. Sonraki yıllarda ülkenin gerek ihracatı gerekse ithalatı artış göstermiş olmakla birlikte son yıllarda durağan bir seyir izlediğini söylemek mümkündür.

Kazakistan, petrol üreticisi bir ülke olması nedeniyle ve sahip olduğu üretim yapısı itibariyle ağırlıklı olarak ham madde ve yarı mamul madde ihracatçısı bir ülke konumundadır. Ülke ihracatının yarısından fazlasını petrol ve petrol ürünleri olușturmaktadır. Tüketim malları ihracatı ise çok sınırlı düzeyde gerçekleşmektedir (Yayar vd., 2012, s.253). Kazakistan’ın 2016 yll ihracatı 36,7 milyar dolar iken ithalatı 25,1 milyar dolardır. 2016 yılı itibariyle Kazakistan'ın ihracatında en önemli partner ülkeler sırasıyla İtalya, Çin, Rusya ve Hollanda’dır. Özellik İtalya ve Çin yıllar itibariyle değişimli olarak Kazakistan’ın en önemli ticari partnerleri haline gelmiştir. İthalatında ise en önemli ülkeler Rusya, Çin ve Almanya'dır. Rusya, Kazakistan'ın ithalatında incelenen dönem boyunca (2003-2016) istisnasız bütün yıllar boyunca en önemli ticari partner olmuştur.

Avrasya ülkeleri içerisinde iktisadi açıdan önemli bir yere sahip olan Türkiye ise coğrafi konumu itibariyle Avrasya ülkeleriyle bir takım ticari ilişkilerde bulunmuş ve önemli miktarlarda dış ticaret potansiyeline ulaşmış bir ülke haline gelmiştir. Trademap (2016:1g) verilerine göre 2003 yılından sonraki dönemde Türkiye’nin en çok ihracat yaptığ 1 ülkelerin sıralaması yıllar itibariyle değişiklik göstermekle birlikte en önemli paya sahip olan ülkeler 2016 y1l itibariyle ve sirasiyla Almanya, İngiltere, Irak, İtalya, ve Amerika Birleşik Devletleri olmuștur. Bununla birlikte incele- nen dönemin tamaminda Almanya, Türkiye'nin ihracat açısından en önemli partner ülke konumundadır. Türkiye'nin ithalatında ise sırasıyla Çin, Almanya, Rusya ve Amerika Birleşik Devletleri en önemli partner ülkeler olarak ön plana çıkmış durumdadır. Özellikle Rusya, 2006 yllından 2015 yılına kadar geçen süreçte aralıksız olarak Türkiyenin en çok ithalat yaptığ 1 ülke konumunda iken 2015 ve 2016 yıllarında bu üstünlügünü Çin’e kaptırmıș durumdadır.

Türkiye, konumu itibariyle Asya ile Avrupa’yı birbirine bağlayan bir ülkedir ve bu durum hem Türkiye’ye hem de Avrasya ülkelerine dış ticaret açısından önemli avantajlar sağlamaktadır. Ayrıca Türkiye’nin jeopolitik ve jeostratejik öneminin farkında olan Kazakistan ve Rusya, dünya ekonomisi üzerinde söz sahibi olabilmek için Avrasya Birliği projesine Türkiye’nin de katılmasını istemişlerdir. Bölgenin önemli ülkeleri tarafından böyle bir isteğin ortaya çıkmasında Türkiye’nin Batı Avrupa ile Asya arasında mal ulaşım açısından önemli bir köprü vazifesi görmesi önemli olmaktadır (Sofyalığlu ve Kartal, 2013, s.525). Türkiye’nin diș ticaret gelir ve gider seviyesi Tablo 1 ve Tablo 2 yardımıyla genel olarak incelendiğinde ise ülkenin hem ihracatının hem de ithalatının diğer Avrasya ülkelerde olduğu gibi 2009 yılına kadar sürekli artış gösterdiği görülmektedir. 2008 yılında yaşanan küresel kriz, diğer Avrasya ülkelerinde olduğu gibi Türkiye'nin de hem ihracat hem de ithalat seviyesinin oranda azalmasına neden olmuş ve 2008 y1linda 132 milyar dolar olan ihracat geliri 2009 yllında 102.1 milyar dolara kadar gerilemiştir. 2010 yılından itibaren Türkiye’nin ihracatı, 2015 yılına kadar 2013 yılındaki çok küçük miktardaki azalış hariç sürekli olarak artış göstermiștir. Ancak 2015 yılında ve 2016 yllında ihracat önemli oranda gerilemiş, $2015 \mathrm{yll}$ itibariyle 143,8 milyar dolar, 2016 yll itibariyle de 142.6 milyar dolara olarak gerçekleşmiştir. Benzer şekilde 2008 yllinda 201,8 milyar dolar olan ithalat harcamalar1 da 2009 yılında 140,8 milyar dolara kadar gerilemiştir. 2009 yılındaki azalışın ardındanTürkiye’nin ithalat harcamaları sonraki iki yıl önemli miktarda artış göstermiş ve 2011 yllı itibariyle 240,8 milyar dolara kadar yükselmiştir. 2015 yılına kadar olan süreçte ithalat harcamalarında küçük çaplı iniş ve çıkışlar yaşanmış, 2015 ve 2016 yıllarında ise önemli oranda azalmış ve 2015 yılında 207,2 milyar dolar, 2016 yılında ise 198,6 milyar dolar olarak gerçekleşmiştir. 


\section{Avrasya Ülkeleri ile Türkiye'nin Dış Ticaret ílişkileri}

Günümüzde önemli bir ekonomik potansiyele sahip olan Avrasya ülkeleriyle Türkiye arasındaki dıș ticaret ilişkileri oldukça gelişmiş durumdadır. Böyle bir gelişim sürecinin ortaya çıkmasında Türkiye ile Avrasya ülkeleri arasındaki coğrafi yakınlık ve ülkeler arası yapılmış olan ikili ve çok taraflı çeşitli iktisadi nitelikteki anlaşmalar önemli rol oynamaktadır. Mevcut konumu itibariyle Türkiye, Güney'le Kuzey'in, Doğu’yla Batı’nın kesiştiği bir kavşak noktası olup, Avrasya’nın merkezinde yer almaktadır (Bayar, 2009, s.32). Özel- likle Rusya, dış ticaret faaliyetleri açısından son zamanlara kadar Türkiye’nin önemli ticari partneri konumundadır. Bu bağlamda Türkiye’nin enerjide dışa bağımlı bir ülke olması ve Rusyảnın da Türkiye'nin ihtiyacı olan enerji kaynaklarına sahip olması nedeniyle, Türkiye ile Rusya arasındaki diş ticaret hacminin önemli miktarlara ulaştığını söylemek mümkündür. Rusya dışında Ukrayna, Kazakistan, Gürcistan ve Azerbaycan ile de önemli miktarlarda ticari faaliyetlerde bulunulmuş, bu ülkelerden önemli miktarlarda dış ticaret geliri elde edilmiş ve bu ülkelere yönelik ithalat harcamaları yapılmıştır.

Tablo 3. Avrasya Ülkelerinin Türkiye'ye Yaptıkları Toplam Ihracat

\begin{tabular}{|lrrrrrrrr|}
\hline & & & & & \multicolumn{3}{r|}{ Milyon ABD Dolar } \\
\hline Ukrayna & $\mathbf{2 0 0 3}$ & $\mathbf{2 0 0 4}$ & $\mathbf{2 0 0 5}$ & $\mathbf{2 0 0 6}$ & $\mathbf{2 0 0 7}$ & $\mathbf{2 0 0 8}$ & $\mathbf{2 0 0 9}$ \\
\hline Belarus & 902.1 & 1868.7 & 2026.7 & 2390.0 & 3645.2 & 4633,2 & 2126.5 \\
\hline Moldova & 22.9 & 26.4 & 37.6 & 38.6 & 67.7 & 108,9 & 79.0 \\
\hline Rusya & 7.2 & 12.2 & 24.6 & 28.4 & 32.0 & 33,4 & 31.7 \\
\hline Gürcistan & 4807.4 & 7440.2 & 10841.4 & 14320.6 & 13392.6 & 27663,4 & 16385.0 \\
\hline Azerbaycan & 107.5 & 118.6 & 121.8 & 123.3 & 171.6 & 262,9 & 218.8 \\
\hline Kazakistan & 182.6 & 275.9 & 388.1 & $1,056.3$ & 626,1 & 107.5 \\
\hline Kirgızistan & 11.0 & 17.0 & 18.1 & 27.2 & 42.9 & 44,8 & 37.6 \\
\hline & & & & & & Milyon ABD Dolar \\
\hline U9.1 & 147.0 & 156.9 & 348.2 & 934.3 & 1903,7 & 791.8 \\
\hline Ukrayna & 3026.6 & 3748.6 & 3685.1 & 3805.5 & $3,561.4$ & 2771,7 & 2547.4 \\
\hline Belarus & 104,8 & 128.5 & 145.2 & 167.8 & 161.3 & 132,7 & 83.9 \\
\hline Moldova & 67,4 & 73.3 & 56.0 & 127.1 & 104.6 & 64,4 & 61.6 \\
\hline Rusya & 13958.6 & 15086.7 & 16103.1 & 15122.0 & $14,755.1$ & 11703,2 & 13698.2 \\
\hline Gürcistan & 206,3 & 214.0 & 134.8 & 184.0 & 222.3 & 168,4 & 173.5 \\
\hline Azerbaycan & 170,8 & 455.7 & 600.0 & 525.9 & 502.4 & 457,5 & 278.1 \\
\hline Kazakistan & 1234,8 & 2574.3 & 3229.0 & 2603.0 & $2,272.4$ & 1275.5 & 851.0 \\
\hline Kurgızistan & 37,2 & 54.4 & 50.1 & 85.6 & 85.9 & 84,0 & 89.9 \\
\hline
\end{tabular}

Kaynak : Trademap, http://www.trademap.org/ (2016:1h.),

(Erişim Tarihi : 15.11.2017) ve (2016:1j.), (Erişim Tarihi : 15.11.2017)

IMF, http://data.imf.org/regular.aspx?key=60998117

(Erişim Tarihi : 18.11.2017)

(Tablo, yukarıda belirtilen sitelerde yer alan verilerden yararlanılarak tarafımızca hazırlanmıștır.) 
Tablo 4. Avrasya Ülkelerinin Türkiye'den Gerçekleştirdikleri Toplam Ithalat

\begin{tabular}{|c|c|c|c|c|c|c|c|}
\hline & \multicolumn{7}{|c|}{ Milyon ABD Dolar } \\
\hline & 2003 & 2004 & 2005 & 2006 & 2007 & 2008 & 2009 \\
\hline Ukrayna & 312.2 & 356.3 & 607.7 & 769.0 & 972.2 & 1949.7 & 952.2 \\
\hline Belarus & 25.6 & 41.3 & 72.2 & 114.1 & 139.0 & 223.1 & 187.6 \\
\hline Moldova & 48.2 & 69.0 & 93.0 & 113.8 & 166.7 & 231.8 & 172.3 \\
\hline Rusya & 927.9 & 1231.1 & 1732.1 & 2722.6 & 4171.9 & 6141.3 & 3221.9 \\
\hline Gürcistan & 111.6 & 201.3 & 282.2 & 519.3 & 708.3 & 916.1 & 694.3 \\
\hline Azerbaycan & 195.1 & 224.9 & 313.0 & 385.0 & 624.6 & 807.3 & 906.0 \\
\hline Kazakistan & 208.9 & 342.3 & 399.7 & 558.2 & 958.8 & 970.7 & 570.8 \\
\hline \multirow[t]{3}{*}{ Kurgızistan } & 25.9 & 33.1 & 33.6 & 39.4 & 50.9 & 91.1 & 72.6 \\
\hline & \multicolumn{7}{|c|}{ Milyon ABD Dolar } \\
\hline & 2010 & 2011 & 2012 & 2013 & 2014 & 2015 & 2016 \\
\hline Ukrayna & 1298.2 & 1481.2 & 1951.8 & 1852.8 & 1298.1 & 851.7 & 1254.0 \\
\hline Belarus & 259.4 & 315.2 & 343.1 & 397.3 & 338.6 & 487.0 & 731.6 \\
\hline Moldova & 205.8 & 366.8 & 388.1 & 380.9 & 300.8 & 285.1 & 271.9 \\
\hline Rusya & 4865.9 & 6352.5 & 6840.0 & 7272.7 & 6654.2 & 4068.8 & 2147.5 \\
\hline Gürcistan & 883.5 & 1279.7 & 1469.6 & 1408.9 & 1728.7 & 1327.3 & 1352.3 \\
\hline Azerbaycan & 771.4 & 1302.4 & 1520.4 & 1480.9 & 1286.6 & 1172.1 & 1285.8 \\
\hline Kazakistan & 616.2 & 729.2 & 786.1 & 926.1 & 1019.3 & 741.9 & 618.1 \\
\hline Kirglzistan & 84.7 & 117.0 & 178.5 & 204.7 & 307.9 & 164.2 & 190.7 \\
\hline
\end{tabular}

Kaynak : Trademap, http://www.trademap.org/ (2016:1k.),

(Erişim Tarihi : 28.11.2017) ve (2016:1m.), (Erişim Tarihi : 28.11.2017)

IMF, http://data.imf.org/regular.aspx?key=60998117

(Erişim Tarihi : 28.11.2017

(Tablo, yukarıda belirtilen sitelerde yer alan verilerden yararlanılarak tarafımızca hazırlanmıştır.)

Trademap (2016) ve IMF'den elde edilen veriler yardımıyla hazırlanan Tablo 3 ve Tablo 4 de Türkiye ile Avrasya ülkeleri arasındaki dış ticaret ilişkilerinin gelişimi görülebilir. Ayrıca Tablo 5 ve Tablo 6 da ise Avrasya ülkelerinin dış ticaretinde (ihracat ve ithalatında) Türkiye’nin payı oransal olarak (\%) görülmektedir. Tablo 3'de, her bir Avrasya ülkesinin Türkiye'ye yaptıkları ihracat miktarları yer almaktadır. Tablolardaki verilerden de anlaşılacağ 1 üzere, incelenen dönemde (2003-2016) Rusya, Avrasya bölgesi ülkeleri içinde yer alan ülkeler içerisinde incelenen dönem (2003-2016) boyunca değer olarak Türkiye’ye en çok ihracatı gerçekleştiren ülke durumundadır.

Türkiye, Rusya’ya en çok tekstil ürünleri ve domates ile turunçgiller ihraç ederken, Rusya'dan ağırlıklı olarak petrol yağları, ham petrol ve doğal gaz ithal et- mektedir (İstanbul Tekstil ve Konfeksiyon İhracatçı Birlikleri, 2013, s.31-32). Rusya’nın Türkiye’ye yönelik olarak gerçekleştirdiği ihracat miktarı ve dolayısıyla ihracat gelirleri tutarı 2008 yılına kadar hızla yükselmiş, ancak 2008 yılındaki küresel kriz nedeniyle 2009 yılında keskin bir şekilde azalmıştır. Söz konusu gerilemenin 2010 yllında da devam ettiği ve sonraki yıllarda Rusyảnın Türkiye'ye yönelik ihracatının bir miktar artmasına karşın genelde inişli çıkışlı bir eğilim sergilediğini söylemek mümkündür. 2016 yılında Rusyảnın Türkiyeden elde ettiği ihracat geliri, Trademap (2016:1n) verilerine göre, 13,7 milyar dolar olarak gerçekleşmiş bulunmaktadır. Bu ihracat değeriyle Rusya’nın toplam ihracatı içerisinde Türkiye’nin payı, Tablo 5'de görüleceği üzere, \% 4,80 oranında gerçekleşmiştir ve Türkiye, Rusyảnın en çok ihracat yaptığı beşinci ülkedir. 
Rusya’nın Türkiye'den gerçekleştirdiği ithalat açısından da benzer bir durum söz konusudur. Tablo 4 incelendiğinde Rusya, Türkiyeden en çok ithalat yapan Avrasya ülkesi konumundadır. 2008 yllındaki kriz nedeniyle Rusya'nın Türkiye'den gerçekleştirdiği ithalat, 2009 yılında önemli oranda azalmış ve 3,2 milyar dolar olarak gerçekleşmiş̧ir. Rusya’nın Türkiye'den gerçekleştirdiği ithalat 2010 yılından 2013 yılına kadar geçen süreçte hızlı bir şekilde artış göstererek 2013 yılında 7,2 milyar dolara kadar yükselmiștir. Ancak 2014 yılından itibaren Rusyảnın Türkiye'den yaptığı ithalat hızlı bir şekilde azalmış ve 2016 yılı itibariyle $2 \mathrm{i} 1$ milyar dolar olarak gerçekleşmiştir. Bu ithalat değeri itibariyle 2016 yılında Türkiye, Tablo 6'da görüleceği üzere Rusyảnın toplam ithalatı içerisinde sadece $\% 1,18$ oranında bir paya sahiptir ve Rusyảnın ithalat yaptığı ülkeler sıralamasında 22. sirada yer almaktadır.

Türkiye’nin diş ticaret faaliyetinde bulunduğu bir diğer önemli Avrasya ülkesi de Ukrayna’dır. Ukrayna, Avrasya ülkeleri içerisinde Türkiye'ye ihracat hacmi açısından 2. sırada önem arz eden bir ülkedir. 20032016 dönemini gösteren Tablo 3 incelendiğinde Ukrayna’nın Türkiye'ye olan ihracatının, 2009 yılında, bir önceki yll yaşanan krizin etkisiyle önemli oranda azaldığı ve 2,1 milyar dolar olarak gerçekleştiği görülmektedir. Sonraki yıllarda ise Ukrayna’nın Türkiye'ye yönelik İhracatı bir miktar yükseldikten sonra 2015 yılına kadar istikrarlı bir seyir izlemiş ve 2014 yılı itibariyle 3,5 milyar dolar olarak gerçekleşmiştir. Ancak
Ukrayna’nın Türkiye’ye yaptığı ihracattan elde ettiği gelir, 2015 yılından itibaren yeniden azalış eğilimine girmiş ve 2015 yilında 2,7 milyar dolar, 2016 yılında da 2,5 milyar dolar olarak gerçekleşmiştir. Bu ihracat rakamıla 2016 yılında Ukrayna’nın ihraç gelirleri içinde Türkiye'nin payı, \% 6,91 olarak gerçekleşmiş durumdadır. Trademap (2016:10) verileri incelendiğinde Türkiye, Ukrayna’nın en çok ihracat yaptı̆̆ 1 ülkeler arasında Rusyadan sonra 2. sırada yer almaktadır. Ukrayna’nın Türkiyeden ithalatı ise nispeten sınırlı düzeylerde kalmıştır. 2008 yılındaki küresel krizden etkilenen Ukrayna ekonomisinin Türkiye'den gerçekleştirdiği ithalat 2009 yllında yine önemli oranda azalarak 1 milyar dolara yakın bir seviyede gerçekleşmiştir. 2016 yllı itibariyle Ukrayna’nın Türkiye’den gerçekleştirdiği ithalat yaklaşık 1,2 milyar dolar seviyesindedir. Bu ithalat değeri itibariyle Ukrayna’nın toplam ithalat harcamaları içerisinde Türkiye'nin payı \% 3,28 oranında gerçekleşmiş durumdadır. Türkiye, Ukrayna’nın en çok ithalat yaptığı 7. ülke konumundadır. Ukrayna, Türkiye’ye başta demir-çelik ürünleri olmak üzere mineral yakıtlar, tarımsal ürünler ve kimyasal gübre şeklindeki hammadde veya yarı mamuller ürünleri ihraç etmektedir. Buna karşın Türkiye'den elektrikli makineler, plastik ürünleri, petrokimya ürünleri, tekstil ve meyve-sebze şeklinde olmak üzere gida maddeleri ithal etmektedir. Ülke ihracatının ve ihraç gelirlerinin artırılabilmesi için demir-çelik sektörünü geliştirmeye yönelik alt yapı çalışmalarının yapılması önem arz etmektedir.

Tablo 5. Avrasya Ülkelerinin Toplam Ihracatı Içinde Türkiye'nin Payı (\%)

\begin{tabular}{|lrrrrrrrrr|}
\hline & $\mathbf{2 0 0 8}$ & $\mathbf{2 0 0 9}$ & $\mathbf{2 0 1 0}$ & $\mathbf{2 0 1 1}$ & $\mathbf{2 0 1 2}$ & $\mathbf{2 0 1 3}$ & $\mathbf{2 0 1 4}$ & $\mathbf{2 0 1 5}$ & $\mathbf{2 0 1 6}$ \\
\hline Ukrayna & 6.92 & 5.36 & 5.88 & 5.48 & 5.36 & 6.01 & 6.61 & 7.27 & 6,91 \\
\hline Belarus & 0.33 & 0.37 & 0.41 & 0.31 & 0.32 & 0.45 & 0.45 & 0.50 & 0,36 \\
\hline Moldova & 2.10 & 2.48 & 4.38 & 3.31 & 2.59 & 5.24 & 4.47 & 3.28 & 3,02 \\
\hline Rusya & 5.91 & 5.43 & 3.52 & 2.92 & 3.07 & 2.87 & 2.96 & 3.40 & 4,80 \\
\hline Gürcistan & 17.56 & 19.92 & 13.64 & 10.40 & 6.02 & 6.29 & 7.77 & 7.64 & 8,21 \\
\hline Azerbaycan & 1.31 & 0.73 & 0.80 & 1.72 & 2.52 & 2.20 & 2.31 & 2,00 & 1,19 \\
\hline Kazakistan & 2.67 & 1.83 & 2.16 & 2.92 & 3.50 & 3.07 & 2.86 & 2.78 & 2,31 \\
\hline Kirglzistan & 2.77 & 3.20 & 2.50 & 2.75 & 2.98 & 4.83 & 4.57 & 5.83 & 6,32 \\
\hline
\end{tabular}

Kaynak :Trademap, http://www.trademap.org/ (Erişim Tarihi : 30.11.2017) ve IMF, http://data.imf.org/regular.aspx?key=60998117

(Erişim Tarihi : 30.11.2017)

(Tablo, yukarıda belirtilen sitelerde yer alan verilerden yararlanılarak Tarafımızca hazırlanmıștır.) 
Tablo 6. Avrasya Ülkelerinin Toplam Ithalatı Içinde Türkiye'nin Payı (\%)

\begin{tabular}{|lrrrrrrrrr|}
\hline & $\mathbf{2 0 0 8}$ & $\mathbf{2 0 0 9}$ & $\mathbf{2 0 1 0}$ & $\mathbf{2 0 1 1}$ & $\mathbf{2 0 1 2}$ & $\mathbf{2 0 1 3}$ & $\mathbf{2 0 1 4}$ & $\mathbf{2 0 1 5}$ & $\mathbf{2 0 1 6}$ \\
\hline Ukrayna & 2.28 & 2.10 & 2.14 & 1.79 & 2.31 & 2.41 & 2.39 & 2.27 & 3.28 \\
\hline Belarus & 0.57 & 0.66 & 0.74 & 0.69 & 0.74 & 0.92 & 0.84 & 1.61 & 2.63 \\
\hline Moldova & 4.73 & 5.26 & 5.34 & 7.07 & 7.45 & 6.94 & 5.66 & 7.15 & 6.77 \\
\hline Rusya & 2.30 & 1.89 & 2.13 & 2.08 & 2.16 & 2.31 & 2.32 & 2.23 & 1.18 \\
\hline Gürcistan & 15.13 & 15.90 & 17.34 & 18.12 & 18.26 & 17.56 & 20.10 & 17.17 & 18.69 \\
\hline Azerbaycan & 11.27 & 14.81 & 11.69 & 13.38 & 15.77 & 13.76 & 14.02 & 12,73 & 17.97 \\
\hline Kazakistan & 2.57 & 2.01 & 2.57 & 1.92 & 1.77 & 1.90 & 2.47 & 2,43 & 2.46 \\
\hline Kirgizistan & 1.04 & 2.45 & 2.63 & 2.75 & 3.32 & 3.42 & 5.37 & 4.04 & 4.96 \\
\hline
\end{tabular}

Kaynak : Trademap, http://www.trademap.org/ (Erişim Tarihi : 30.11.2017) ve IMF, http://data.imf.org/regular.aspx?key=60998117 (Erişim Tarihi : 30.11.2017)

(Tablo, yukarıda belirtilen sitelerde yer alan verilerden yararlanılarak tarafımızca hazırlanmıştır.)

Son olarak Türkiye ile önemli ticari ilişkiler kuran bir diğer önemli Avrasya ülkesi de Kazakistan'dır. İki ülke arasındaki ihracat hacmi 2009 yılı hariç 2013 yılına kadar sürekli olarak artış göstermiş, sonraki yıllarda bir miktar azalmış ve 2016 yılı itibariyle 851 milyon dolar olarak gerçekleşmiştir. Bu ihracat değeriyle Türkiye'ye yapılan ihracat, Kazakistan'ın toplam ihraç gelirlerinin \% 2,31'ini teşkil etmektedir. Ayrıca Türkiye, Kazakistan’ın en çok ihracat yaptığı ülkeler sıralamasında 12. sırada yer almaktadır. Tablo 4'de yer alan iki ülke arasındaki ithalat değerleri incelendiğinde ise ihracat değerlerine paralel bir eğilimin geçerli olduğu görülmektedir. Aynen ihracatta olduğu gibi 2008 yllına kadar artış gösteren Kazakistan’n Türkiye'den yaptığı ithalat harcamaları küresel krizin etkisiyle 2009 yılında önemli oranda gerilemiş, bu gerilemenin ardından 2014 yılına kadar düzenli olarak yükselerek 1 milyar dolar seviyesine ulaşmıştır. Kazakistan’ın Türkiye'den yaptığ 1 ithalat 2016 yılında ise 618 milyon dolar olarak gerçekleşmiş bulunmaktadır. Bu ithalat değerleri itibariyle Kazakistan’ın, toplam ithalatının \% 2,46'sının Türkiye'den gerçekleștiğini söylemek mümkündür. Ayrıca bu veriler doğrultusunda Türkiye, Kazakistan’n en çok ithalat yaptığ 1 ülkeler sıralamasında 7. sırada yer almaktadır. Dış ticaret bağlamında Kazakistan, Türkiye'den ağırlıklı olarak çeşitli nitelikte makine ve cihazlar, plastik kullanılarak üretilmiş olan mamul eşyalar ve elektrikli makinalar ile bu makinalara ait araç-gereçleri ithal ederken, Türkiye'ye bakır, demir-çelik ve mineral ya- kıtlar ihraç etmektedir. İki ülke arasındaki dış ticarette dış ticaret açığının Türkiye aleyhine olmasında Türkiye'nin Kazakistan'dan gerçekleştirdiği ithalatın ağırlıklı olarak mineral yakıtlara ve hammaddelere dayalı olması önemli rol oynamaktadır (Yayar vd., 2012, s.253). Bu nedenle Türkiye açısından Kazakis$\tan$ ile yürütülen dış ticaret faaliyetlerinin geliştirilmesi yanında bu ülkeyle gerçekleştirilen ihracatın ve ithalatın kompozisyonunun da değiştirilmesi, bu ülke özelinde ortaya çıkan dış ticaret açığının düşürülmesi açısından önemlidir.

Çalışmanın bundan sonraki bölümünde incelenen Avrasya ülkelerinin sabit sermaye yapılarının, döviz kurlarının ve büyümelerinin dış ticaretleri üzerine etkileri panel veri yöntemiyle ekonometrik olarak analiz edilmiştir.

\section{Ekonometrik Yöntem}

Ekonometrik yöntemlerde sadece zaman serisi veya sadece yatay kesit verileriyle çalışmak yetersiz bir durumdur. Bunun nedeni yatay kesit uygulamalarında değişkenlerin değişimleri dışlanırken, zaman serisi uygulamalarında belirli zamanın altındaki veriler kapsanmadığı için doğru sonuçlar alınamamaktadır. Bu yüzden bu çalışmada panel veri analizi kullanılmıştır. Panel veri analizinin kullanılmasıyla verilerin hem zaman hem de yatay kesit boyutu bir arada ele alınmaktadır (Turhan ve Taşseven, 2010:140). Panel veride aynı $n$ değerleri için iki ya da daha fazla zaman 
dönemindeki gözlemlerden oluşur. Panel veri analizinin fonksiyonel şekli veri seti $\mathrm{X}$ ve $\mathrm{Y}$ değişkenine ait gözlemleri içerdiğinden aşağıdaki gibi gösterilir.

Yit=Bo+B1Xit+uit

ve

(Xit ve Yit) $\mathrm{i}=1, \ldots \ldots \ldots \mathrm{n} \quad$ ve $\quad \mathrm{t}=1 \ldots \ldots \ldots \mathrm{t}$

t ve i kesitleri göstermektedir. Panel veri analizinde yatay kesit ve zaman serileri panel modele dönüştürüldükten sonraki aşama sabit etkiler mi yoksa rassal etkiler tarafından tespit edildiğinin belirlenmesidir (Baltagi, 2005:11). Sabit etkiler modelinde, dişlanan değişkenlerin değiştiği halde zamana göre değişmediği durumu ifade eder. Katsayıların birime ve zamana göre değiştiğini varsayan modellere sabit etkili modeller denir. Sabit etkiler modeli;

$\mathrm{Y}=\mathrm{a} 1+\mathrm{a} 2 \mathrm{D} 2 \mathrm{i}+\ldots+\mathrm{an}+\mathrm{Dni}+\mathrm{B} 2 \mathrm{X} 2 \mathrm{it}+\mathrm{uit}$

şeklindedir. Kullanılan kukla değişkenlerde modelin doğruluğu konusunda tam bilgi vermemesi durumunda rassal etki modeli önerilmektedir (Baltagi, 2005:12). Ayrıca modelde kullanılacak olan veriler rassal olarak seçilmiş ise sabit etkiler modeli yerine rassal etkiler modeli tercih edilmektedir (Baldemir ve Keskiner, 2004:48). İki model arasında hangisinin uygulanacağını belirlemek için Hausman tarafından önerilen test istatistiği ile incelenmektedir. Hausman testi birim ve zaman katsayılarının modeldeki bağımsız değişkenlerden ilişkisiz olduğunun hipotezinin test edilmesidir. $k$ serbestlik dereceli tesadüfü etkiler tahmincisi doğrudur hipotezi altında ki-kare dağıllmı göstermektedir (Green, 2003).

\section{Ekonometrik Analiz}

Ekonmetrik analizin yapılabilmesi için 1998-2016 dönemine ait, Dünya bankası veri tabanından elde edilen yıllık veri setleri kullanılmıştır. Veri setimizde dış ticaret hacmi, döviz kuru, sabit sermaye yatırımları ve büyüme değişkenleri kullanılmıştır. Ekonometrik analiz yapılan ülkeler ise Azerbaycan, Kırgızistan, Moldova, Rusya, Türkiye, Belarus, Gürcistan, Kazakistan ve Ukrayna'dır. Çalışmadaki amaç ülkelerin dış ticaretini etkileyen değişkenlerin yönünün ve şiddetinin belirlenmektir. Bunun için ekonometrik yöntem olarak panel veri analizi kullanılmıştır. Panel veri analizi, zaman serisi ve yatay kesiti birlikte ele alan ve daha sağlıklı sonuçlar veren bir ekonometrik yöntemdir. Analiz gerçekleştirilirken Dünya Bankası veri tabanında Özbekistan, Türkmenistan ve Tacikistan’a ait veriler, incelenen yıllar itibariyle zaman serisi açısından eksiklik arz ettiğin için analize dahil edilmemiştir.

Ekonometrik analize başlamak için önce veri setimizdeki değişkenlerin durağanlığının sınanması gerekir. Bunun için birim kök analizinin yapılması gerekir. Aşağıdaki tablo 7'de birim kök analizimiz için sonuçlar verilmiştir.

Tablo 7'de görüldüğü üzere yapılan birim kök sinamasında LLC, IPS, ADF ve PP birim kök testleri sonucuna göre olasılık değerleri, trendsiz ve trendli olarak değişkenler seviyesinde durağandır. Bir sonraki aşamada, panel veri analizinde kullanılmak üzere sabit yadarassal etki modelleri arasında seçim yapmak için Hausman testi yapılmıştır.

Tablo 8'deki Hausman testi sonuçlarına göre $0.6641>0.050$ olduğu için Ho kabul edilir. Yani rassal etki vardır denilir. Panel veri analizi için rassal etki modeli kurulur. 
Tablo 7. Birim Kök Testi Sonuçları

\begin{tabular}{|lcccc|}
\hline \multicolumn{1}{|c}{ Değişkenler-Yöntem } & \multicolumn{2}{c}{ Trendsiz } & \multicolumn{2}{c|}{ Trendli } \\
\hline Büyüme Oranı & İstatistik & Olasılık & İstatistik & Olasılık \\
\hline Levin, Lin \&Chu t (LLC) & -2.59436 & 0.0047 & -4.62173 & 0.0000 \\
\hline $\begin{array}{l}\text { Im, PesaranandShin W- } \\
\text { stat (IPS) }\end{array}$ & -3.31754 & 0.0005 & -3.45878 & 0.0003 \\
\hline ADF - FisherChi-square & 44.9910 & 0.0004 & 44.9848 & 0.0004 \\
\hline PP - FisherChi-square & 118.674 & 0.0000 & 101.183 & 0.0000 \\
\hline \multicolumn{1}{|c|}{ Döviz Kuru } & İstatistik & Olasılık & İstatistik & Olasıllk \\
\hline Levin, Lin \&Chu t* & -19.2285 & 0.0000 & -13.6716 & 0.0000 \\
\hline Im, PesaranandShin W-stat & -13.8056 & 0.0000 & -7.65332 & 0.0000 \\
\hline ADF - FisherChi-square & 138.441 & 0.0000 & 82.7368 & 0.0000 \\
\hline PP - FisherChi-square & 37.7423 & 0.0042 & 26.6201 & 0.0864 \\
\hline \multicolumn{1}{c}{ Dıș Ticaret } & İstatistik & Olasılık & İstatistik & Olasılık \\
\hline Levin, Lin \&Chu t (LLC) & -3.11736 & 0.0009 & -3.21270 & 0.0007 \\
\hline $\begin{array}{l}\text { Im, PesaranandShin W- } \\
\text { stat (IPS) }\end{array}$ & -2.57973 & 0.0049 & -2.42514 & 0.0077 \\
\hline ADF - FisherChi-square & 35.6893 & 0.0077 & 35.7113 & 0.0077 \\
\hline PP - FisherChi-square & 25.5114 & 0.1115 & 37.8084 & 0.0041 \\
\hline Sabit Sermaye Yatırımı & İstatistik & Olasılık & İstatistik & Olasıllk \\
\hline Levin, Lin \&Chu t (LLC) & -5.26570 & 0.0000 & -5.68273 & 0.0000 \\
\hline $\begin{array}{l}\text { Im, PesaranandShin W- } \\
\text { stat (IPS) }\end{array}$ & -4.88212 & 0.0000 & --3.91881 & 0.0000 \\
\hline ADF - FisherChi-square & 61.0971 & 0.0000 & 48.9142 & 0.0001 \\
\hline PP - FisherChi-square & 71.5150 & 0.0000 & 61.7318 & 0.0000 \\
\hline
\end{tabular}

Tablo 8. Hausman Testi

\begin{tabular}{|lccc|}
\hline Test Özeti & Ki-kare İstatistiği & Ki-kare. d.f. & Olasılık \\
\hline Kesitler Aras1-Rassal & 1.579269 & 30.300993 & 0.6641 \\
\hline
\end{tabular}

Tablo 9. Rassal Etki Modeli Regresyon Sonuçları

\begin{tabular}{|c|c|c|c|c|}
\hline Değişken & Katsayı & Standart Hata & T- İstatistiği & Olasılık \\
\hline BÜYÜME & 0.693937 & 0.223343 & 3.107043 & 0.0022 \\
\hline DÖVİZ & 3.554053 & 2.483951 & 1.430807 & 0.1544 \\
\hline SSY & 8.637431 & 4.316737 & 2.000917 & 0.0470 \\
\hline C & 86.44855 & 10.79339 & 8.009397 & 0.0000 \\
\hline
\end{tabular}


Yapılan analiz sonucunda ulaşılan fonksiyon şu şekildedir.

\section{TİCARET=86.44855+0.693937 BÜYÜME + 3.554053 DÖVİZ KURU + 8.637431 SSY}

Tablo 9 incelendiğinde sabit sermaye yatırımlarındaki \% 1'lik bir artışın ticareti 8.637431oranında artırdığı anlaşılmaktadır. Aynı şekilde kurdaki \% l'lik bir artış da ticareti 3.554053oranda arttırmaktadır. \% 1'lik büyümenin gerçekleşmesi ise, ticaretin 0.693937 oranda artmasına neden olmaktadır. Sabit sermaye yatırımlarının iyileşmesi, dış ticaretin oluşmasına zemin hazırlayacağından sabit sermaye yatırımları dış ticareti arttırıcı bir unsurdur. Kurdaki artış, dış ticaretin artmasına neden olur. Artışın nedeni ise diş ticarette kullanılan girdilerin ithal edilmesidir. Büyüme katsayısının pozitif çıkması, bu ülkelerin dış ticarette önemli pay aldığının ve dış ticaretin büyüme üzerine etkisinin pozitif olduğunun göstergesidir. $\mathrm{Bu}$ nedenle incelenen ülkelerde dışa bağımlılık azaltılmış ve ithalat odaklı politikalar yerine ihracat odalı politikaların belirlenmiştir.

\section{Sonuç}

Avrasya ülkelerinin iktisadi gelişmişlikleri, coğrafi konumları ve önemli enerji kaynaklarına sahip olmaları, bu ülkelerin 2008 yılına kadar Türk ekonomisi üzerindeki önemli etkilere sahip olmasına neden olmuştur. Özellikle Rusya, Türkiye’nin en önemli ticari ortağı konumunda bulunmaktadır. Ayrıca Ukrayna, Kazakistan, Belarus ve Azerbaycan ile de önemli bir ticaret hacmine ulaşılmıştır. Ancak 2008 yılında yaşanan küresel nitelikteki ekonomik kriz, dış ticaret faaliyetlerini olumsuz etkileyerek hem Avrasya bölgesindeki ülkelerin hem Türkiye'nin dış ticaret hacminin önemli oranda gerilemesine neden olmuştur. Sonraki ylllarda ise krizin etkisinin hafiflemesiyle ülkelerin dış ticaret hacimlerinde yeniden yükselişler söz konusu olsa da yllar itibariyle ihracat ve ithalat rakamlarında dalgalı bir seyrin hakim olduğunu söylemek mümkündür. 2008 küresel krizi ve sonrasında Avrasya ekonomilerinin Türkiye ile olan dış ticareti, 1998-2016 yıllarını kapsayan dış ticaret, döviz kuru, sabit sermaye yatırımları ve büyüme değişkenlerine ait Dünya Bankası veri tabanından elde edilen yıllık veri setleri kullanılarak panel veri yöntemiyle analiz edilmiştir.
Yapılan ekonometrik analizin temel amacı Avrasya ülkelerinin diş ticaretini etkileyen değişkenlerin yönünü ve şiddetinin belirlenmesini sağlamaktır. $\mathrm{Bu}$ sayede her bir Avrasya ülkesinin dış ticarete yaptığ katkıların görülebilmesi amaçlanmaktadır. Yapılan analiz neticesinde Azerbaycan, Belarus, Gürcistan, Kurgızistan, Kazakistan, Moldova, Rusya, Türkiye ve Ukrayna’nın sabit sermaye yatırımlarının, döviz kurunun ve büyümenin dış ticaret üzerine olumlu etkisi olduğu sonucuna ulaşılmıştır.

Ayrıca yapılan analiz sonuçlarından Türkiye'de yapılan sabit sermaye yatırımlarının, döviz kurunun ve büyümenin dış ticareti olumlu yönde etkilediği anlaşılmaktadır. Böyle bir sonucun ortaya çıkmasında Türkiye'de sabit sermaye yatırımlarının tamamlanmış olması ve etkin bir şekilde uygulanan açık piyasa işlemleri sayesinde döviz kuruna müdahale edilerek kurun kontrol altında tutulması belirleyici olmuştur. Bu sayede Türkiye Avrasya ülkelerine kiyasla kurdaki dalgalanmalardan daha az olumsuz etkilenmiş ve daha rahat diş ticaret yapabilmiştir. Bununla birlikte 2008 yılındaki küresel krizden önemli ölçüde etkilenen $A B D$ ve Avrupa Birliği ülkeleriyle gerçekleştirdiği ticaret hacminin daralmasına karşın Türkiye, Avrasya ülkeleriyle gerçekleştirdiği ticareti artırarak kendine alternatif piyasalar oluşturabilmiş, ticaret yapılan ülke kompozisyonu değişmiş ve bu sayede krizin etkileri sınırlı kalmıştır.

\section{Kaynakça}

Baldemir, E. ve Keskiner, A. (2004). Devalüasyon, Para, Reel Gelir Değişkenlerinin Dış Ticaret Üzerine Etkisinin Panel Data Yöntemiyle Türkiye İçin İncelenmesi, Dokuz Eylül Üniversitesi Sosyal Bilimler Enstitüsü Dergisi, 6(4), 44-59.

Baltag1, H. B. (2005). Econometric Analysis of Panel Data. 3.Edition, England: John Wiley\&SonsGmbh. West Sussex.

Bayar, F. (2009). Küreselleşme kavramı ve küreselleşme sürecinde Türkiye. Uluslararası Ekonomik Sorunlar Dergisi, (32), 25-34. http://www.mfa.gov.tr/data/ Kutuphane/yayinlar/EkonomikSorunlarDergisi/ sayi32/firatbayar.pdf 
Dış Ekonomik İlişkiler Kurulu (DEİK). (2012). Beyaz Rusya Ülke Bülteni, Ankara: Belarus Ülke BülteniDEIK, https://www.deik.org.tr/uploads/belarusulke-bulteni.pdf

Golovko, A. (2013). Avrasya ülkelerinin dünya ticaret sistemine entegrasyonu. Çankırı Karatekin Üniversitesi Uluslararasi Avrasya Strateji Dergisi, 2(2), 167-192. http://www.arastirmax.com/en/system/ files/dergiler/169983/makaleler/2/2/arastirmaxavrasya-ulkelerinin-dunya-ticaret-sistemine-entegrasyonu.pdf

Green,W.H. (2003). Econometric Analysis: Analysis of Panel. 5.Edition,New Jersey: PrenticeHall.

IMF, http://data.imf.org/regular.aspx?key=60998117 (Erişim Tarihi : 28.11.2017)

İstanbul Tekstil ve Konfeksiyon İhracatçı Birlikleri (İTKİB), (2013), RusyaFederasyonu (Hazır Giyim ve Konfeksiyon Sektörü Açısından), Temel Ekonomik Göstergeler (Genel ve Sektörel Bilgiler), İstanbul: İTKİB

Karluk, S. R. (2011). Küresel krizin kirgizistan ekonomisine etkisi ve Türkiye-Kirgizistan ekonomik ilişkilerindeki gelişmeler, Selahattin Sarı (Ed.), JusupPirimbaev (Ed.), Alp H. Gencer (Ed.), AynuraTurdalieva (Ed.), International Conference On EurasıanEconomies(s. 47-56). Bişkek: Manas Üniversitesi Yayını

Kesgingöz, H. (2015). Döviz kurundaki değişimin Türkiye-Kırgızistan dış ticaretine etkisi: Var analizi. Kastamonu Üniversitesi İktisadi ve İdari Bilimler Fakültesi Dergisi, 8, 91-99. http://dergipark.gov.tr/ iibfdkastamonu/issue/29398/317879

Mercan, M. (2014). Ekonomik büyümenin belirleyicileri ve 2008 krizi: Orta Asya ülkeleri ve Türkiye ekonomisi için panel veri analizi. Yönetim ve Ekonomi Dergisi, 21(1), 125-142. http://www2.bayar.edu.tr/ yonetimekonomi/dergi/pdf/C21S12014/125-142. pdf
Narin, M. ve Marşap, A. (2010). Küresel Kriz Sonrası Türk Cumhuriyetleri Ekonomileri ve Türkiye ile Ticari İliskileri, Selahattin Sarı (Ed.), Alp H. Gencer (Ed.), E. Ayșen Hiç Gencer (Ed.), Internatıonal Conference On EurasianEconomies 2010, (s. 5-13). İstanbul: Şanofset

Rangsimaporn, P. (2006). Interpretations of eurasianism: justifying Russiasrole in eastAsia. EuropeAsia Studies, 58(3), 371-389. https://www.tandfonline.com/doi/full/10.1080/09668130600601750?sc roll=top\&needAccess=true

Sharma, A. ve Dietrich, M. (2004), The Indian economy since liberalisation: the structure and composition of exports and industrial transformation(1980-2000), Sheffield Economic Research Paper Series, SERP Number: 2004004, http://eprints. whiterose.ac.uk/9890/1/SERP2004004.pdf (Erişim:21.09.2017)

Sofyalığlu, Ç. ve Kartal, B. (2013), Türkiye ve Avrasya Ekonomik Topluluğu Ülkelerinin Lojistik Performans İndekslerinin Karşılaştırılması ve Bazı Çıkarımlar, Selahattin Sarı (Ed.), Alp H. Gencer (Ed.), İlyas Sözen (ed.), Internatıonal Conference on EurasianEconomies 2013, (s. 524-531). St. Petersburg: Çetin Ozalit

Solak, F. ve Sarıdoğan, E. (2011). Küresel iktisadi krizin Türk Cumhuriyetleri’ne etkileri. Marmara Üniversitesi İ.I.B.F. Dergisi, 30(1) 93-115. http://dosya. marmara.edu.tr/ikf/iib-dergi/2011-1/93-115solaksaridogan.pdf

Taylor, T. (2002), Thetruthaboutglobalization.ThePublicInterest,147, 24-44. http://www.slembeck.ch/ pdf/taylor.pdf

Trademap (2016:1a). https://www.trademap.org/Country_SelProductCountry_TS.aspx?nvpm $=1 \mid 6$ 43||||TOTAL|||2|1|1|2|2|1|2|1|1 (Erişim Tarihi: 22.10.2017) 
Trademap (2016:1b). http://www.trademap.org/Country_SelProductCountry.aspx?nvpm=1|031||||T OTAL ||2|1|2|1|1||2|1|1 (Erişim Tarihi : 24.10.2017)

Trademap(2016:1c). http://www.trademap.org/Country_SelProductCountry_TS.aspx?nvpm $=1 \mid 4$ 17||||TOTAL|||2|1|1|1|2|1|2|1|1 (Erişim Tarihi : 24.10.2017)

Trademap(2016:1d). http://www.trademap.org/Country_SelProductCountry.aspx?nvpm $=1|031||| \mid \mathrm{T}$ OTAL|||2|1|2|1|1||2|1|1 (Erişim Tarihi:25.10.2017)

Trademap(2016:1e). http://www.trademap.org/Country_SelProductCountry_TS.aspx?nvpm $=1$ | 417||||TOTAL|||2|1|1|1|2|1|2|1|1 (Erişim Tarihi:25.10.2017)

Trademap (2016:1f). https://www.trademap.org/Country_SelProductCountry_ TS.aspx?nvpm=1|398|||| TOTAL|||2|1|1|2|2|1|2|1|1 (Erişim Tarihi : 06.11.2017)

Trademap (2016:1g). https://www.trademap.org/Country_SelProductCountry_TS.aspx?nvpm $=1 \mid 7$ 92||||TOTAL|||2|1|1|2|2|1|2|1|1 (Erişim Tarihi : 10.11.2017)

Trademap (2016:1h). http://www.trademap.org/ Bilateral_TS.aspx?nvpm $=1|417||792| \mid$ TOT AL|||2|1|1|2|2|1|1|1|1 (Erişim Tarihi:15.11.2017)

Trademap (2016:1j). http://www.trademap. org/Bilateral.aspx?nvpm $=1|031||792| \mid$ TOT AL |||2|1|2|2|1|1|1|1|1 (Erişim Tarihi:15.11.2017)

Trademap (2016:1k). https://www.trademap.org/ Bilateral_TS.aspx?nvpm $=1|643||792| \mid$ TOT AL|||2|1|1|1|2|1|1|1|1 (Erişim Tarihi : 28.11.2017)
Trademap (2016:1m). https:/www.trademap.org/ Bilateral_TS.aspx?nvpm $=1|112||792| \mid$ TOT AL|||2|1|1|1|2|1|1|1|1 (Erişim Tarihi : 28.11.2017)

Trademap (2016:1n). https://www.trademap.org/ Bilateral_TS.aspx?nvpm $=1|643||792| \mid$ TOT AL|||2|1|1|2|2|1|1|1|1 (Erişim Tarihi : 05.12.2017)

Trademap (2016:1o). https://www.trademap.org/Country_SelProductCountry_TS.aspx?nvpm $=1 \mid 8$ 04||||TOTAL|||2|1|1|2|2|1|2|1|1 (Erişim Tarihi : $05.12 .2017)$

Turhan, M ve Taşseven, Ö. (2010). Yönetim fonksiyonlarının uygulandığı alanlarda ortaya çıkan hata değerlerinin oluşturduğu yeni ilişkilerin panel veri modelleri ile irdelenmesi, İstanbul Üniversitesi İktisat Fakültesi Ekonometri ve İstatistik Dergisi, (11), 128-153.

Türkiye Ukrayna Sanayici ve İşadamları Birliği (TUSİB), (2013), TUSïB Ukrayna Ülke Raporu, Kiev: TUSİ. http://tusib.org/wp-content/ uploads/2015/08/2013-Annual-Report.pdf

Yayar, R., Demir, Y. ve Birol, Y. E. (2012), Geçiş Ekonomileri Bağlamında Türkiye-Kazakistan Dış Ticaretine Uygulamalı Bir Bakış, Selahattin Sarı (Ed.), Alp H. Gencer (Ed.), Bekir Aşık (Ed.), AynuraTurdalieva (Ed.), International Conference on EurasianEconomies 2012, (s.250-258). Almaty: Turan UniversityPress. 